\title{
Asuhan Keperawatan Psikososial Pada Ny. M Dengan Masalah Gangguan Citra Tubuh Di Rengas Pulau
}

\author{
Keren Aristha Laia \\ Kerenlaia02@gmail.com
}

\section{BAB 1}

\section{PENDAHULUAN}

\subsection{Latar Belakang}

Ca Mammae atau kanker payudara merupakan kanker pada jaringan payudara yang timbul akibat pertumbuhan yang tidak normal sejumlah sel di payudara secara tidak terkendali (Bulu, 2020). Kanker ini terjadi karena akibat adanya perubahan dalam fisiologi sel yang akhirnya tumbuh menjadi ganas serta mempunyai ciri seperti benjolan dengan diameter $1 \mathrm{~cm}$, dapat diraba oleh penderita sendiri, mengeluarkan cairan abnormal dari puting susu (bercampur darah), luka menahun dan melebar pada puting susu (Guntari \& Suariyani, 2016).

Ca Mammae juga merupakan salah satu jenis kanker terbanyak di Indonesia. Angka kejadiannya selalu meningkat ditiap tahunnya. Berdasarkan data Riset Kesehatan Dasar (Riskesdas, 2018) prevalensi tumor/kanker di Indonesia menunjukkan adanya peningkatan pada tahun 2013 yaitu mulai dari 1,4/1000 penduduk menjadi 1,79/1000 penduduk di tahun 2018 Data lainnya, yaitu Globocan menyebutkan pada tahun 2018 kanker di Indonesia sebanyak 136,2/100.000 penduduk. Sedangkan untuk angka kejadian pada perempuan yang tertinggi adalah kanker payudara atau $\mathrm{Ca}$ Mammae yaitu sebesar 42,1/100.000 penduduk dengan rata-rata kematian 17/100.000 penduduk. Angka ini menempatkan Indonesia menjadi urutan ke-8 dengan kasus 
terbanyak di Asia Tenggara dan peringkat ke 23 se-Asia.

Penderita Ca Mammae mengalami penurunan citra tubuh karena terdapat bagian tubuh di payudara yang rusak, sehingga mengakibatkan harga diri situasional, sehingga harga diri dikaitkan dengan hubungan interperonal yang buruk dan beresiko terjadinya depresi sehingga perasaan negatif mendasari hilangnya kepercayaan diri dan harga diri individu dan menggambarkan gangguan harga diri (Pardede, Hutajulu, \& Pasaribu, 2020). Menurut National Eating Disorder, citra tubuh atau biasa juga disebut sebagai body image adalah bagaimana seseorang melihat diri sendiri ketika ia berkaca atau ketika ia membayangkan dirinya dalam pikiran. Citra tubuh adalah sikap individu yang disadari atau tidak disadari terhadap tubuhnya termasuk persepsi serta perasaan masa lalu dan sekarang tentang ukuran, fungsi, penampilan dan potensi (Idris, 2015)

Citra tubuh merupakan sikap individu terhadap tubuhnya, baik secara sadar maupun tidak sadar, meliputi performance, potensi tubuh, fungsi tubuh serta persepsi dan perasaan tentang ukuran tubuh dan bentuk tubuh. Pandangan realistis terhadap diri, menerima dan menyukai bagian tubuh akan memberi rasa aman, terhindar dari rasa cemas dan menigkatkan harga diri. Persepsi dan pengalaman individu terhadap tubuhnya dapat mengubah citra tubuh secara dinamis (Hamud, Waliyo \& Mustikasari, 2017)

Gangguan citra tubuh dapat mengakibatkan kekacauan pada cara seseorang merasakan citra tubuhnya. Evaluasi diri dan perasaan tentang kemampuan diri negatif, yang dapat diekspresikan secara langsung atau tidak langsung. Suatu gangguan citra tubuh dapat diketahui perawat dengan mewawancarai dan mengamati pasien secara berhati-hati untuk mengidentifikasi bentuk ancaman dalam citra tubuhnya (fungsi signifikan bagian yang terlibat, pentingnya penglihatan dan penampilan fisik bagian yang terlibat); arti kedekatan pasien terhadap anggota keluarga dan anggota penting lainnya dapat membantu pasien dan keluarganya (Hamdani, 2017). 
Survei awal yang dilakukan Di Rengas Pulau Kec. Medan Marelan maka ditemukan pasien dengan gangguan citra tubuh akibat Ca Mammae yang bernama Ny.M dengan dengan gangguan citra tubuh Di Rengas Pulau Kec. Medan Marelan.

\subsection{Rumusan masalah}

Berdasakan uraian latar belakang maka penulis membuat rumusan masalah sebagai berikut: Asuhan Keperawatan Pada Ny.M dengan gangguan citra tubuh di Rengas Pulau.

\subsection{Tujuan}

\subsubsection{Tujuan Umum}

Mengetahui gambaran gangguan citra tubuh Ny. M ca mammae di Rengas Pulau

\subsubsection{Tujuan Khusus}

a. Mahasiswa mampu melakukan pengkajian pada Ny.M dengan masalah gangguan citra tubuh.

b. Mahasiswa mampu menegakkan diagnosa pada Ny.M dengan masalah gangguan citra tubuh.

c. Mahasiswa mampu membuat intervensi pada Ny.M dengan masalah gangguan citra tubuh.

d. Mahasiswa mampu melakukan implementasi pada Ny.M dengan masalah kecemasan.

e. Mahasiswa mampu membuat evaluasi pada Ny.M dengan masalah kecemasan.

\section{BAB 2}

\section{TINJAUAN TEORITIS}




\subsection{Konsep Citra Tubuh}

\subsubsection{Definisi Citra Tubuh}

Citra tubuh adalah cara individu mempersepsikan ukuran, penampilan, dan fungsi tubuh dan bagian-bagiannya. Citra tubuh memiliki aspek kognitif dan afektif. Kognitif adalah pengetahuan materi tubuh dan kelekatannya, afektif mencakup sensasi tubuh, seperti nyeri, kesenangan, keletihan, gerakan fisik. Citra tubuh adalah gabungan dari sikap, kesadaran ,dan tidak kesadaran, yang dimiliki seseorang terhadap tubuhnya.

Citra tubuh dipengaruhi oleh pandangan pribadi tentang karakteristik dan kemampuan fisik dan oleh persepsi dari pandangan orang lain (Potter \& Perry, 2017). Citra tubuh (body image) meliputi perilaku yang berkaitan dengan tubuh, termasuk penampilan, struktur, atau fungsi fisik. Rasa terhadap citra tubuh termasuk semua yang berkaitan dengan seksualitas, feminitas dan maskulinitas, berpenampilan muda, kesehatan dan kekuatan (Potter \& Perry, 2017). Citra tubuh merupakan sikap individu terhadap tubuhnya, baik secara sadar maupun tidak sadar, meliputi performance, potensi tubuh, fungsi tubuh serta persepsi dan perasaan tentang ukuran tubuh dan bentuk tubuh. Citra tubuh dapat mempengaruhi bagaimana cara individu mempersepsikan tubuhnya, baik secara sadar maupun tidak sadar yang meliputi ukuran, fungsi, penampilan, dan potensi tubuh berikut bagian-bagiannya. Dengan kata lain, citra tubuh adalah kumpulan sikap individu, baik yang disadari ataupun tidak yang ditujukan terhadap dirinya. Beberapa hal terkait citra tubuh antara lain:

1. Fokus individu terhadap bentuk fisiknya.

2. Cara individu memandang dirinya berdampak penting terhadap aspek psikologis individu tersebut.

3. Citra tubuh seseorang sebagian dipengaruhi oleh sikap dan respon orang lain terhadap dirinya, dan sebagian lagi oleh eksplorasi individu terhadap dirinya.

4. Gambaran yang realistis tentang menerima dan menyukai bagian tubuh akan memberi rasa aman serta mencegah kecemasan dan 
meningkatkan harga diri.

5. Individu yang stabil, realistis dan konsisten terhadap citra tubuhnya dapat mencapai kesuksesan dalam hidup (Mubarak, Wahit \& Chayatin, 2008).

\subsubsection{Faktor Yang Memperngaruhi Citra Tubuh}

Citra tubuh dipengaruhi oleh pertumbuhan kognitif dan perkembangan fisik. Perubahan perkembangan yang normal seperti pertumbuhan dan penuaan mempunyai efek penampakan yang lebih besar pada tubuh dibandingkan dengan aspek lainnya dari konsep diri. Selain itu, sikap dan nilai kultural dan sosial juga mempengaruhi citra tubuh. Pandangan pribadi tentang karakteristik dan kemampuan fisik dan oleh persepsi dan pandangan orang lain. Cara individu memandang dirinya mempunyai dampak yang penting pada aspek psikologinya. Pandangan yang realistik terhadap dirinya, menerima dan mengukur bagian tubuhnya akan membuatnya lebih merasa aman sehingga terhindar dari rasa cemas dan meningkatkan harga diri. Proses tumbuh kembang fisik dan kognitif perubahan perkembangan yang normal seperti pertumbuhan dan penuaan mempunyai efek penampakan yang lebih besar pada tubuh bila dibandingkan dengan aspek lain dari konsep diri (Potter \& Perry, 2017).

\subsubsection{Klasifikasi Citra Tubuh}

Menurut Riyadi (2015), citra tubuh normal adalah persepsi individu yang dapat menerima dan menyukai tubuhnya sehingga bebas dari ansietas dan harga dirinya meningkat. Gangguan citra tubuh adalah persepsi negatif tentang tubuh yang diakibatkan oleh perubahan ukuran, bentuk, struktur, fungsi, keterbatasan, makna dan obyek yang sering berhubungan dengan tubuh (Riyadi, 2015). Stressor pada tiap perubahan, yaitu :

a. Perubahan ukuran tubuh : berat badan yang turun akibat penyakit .

b. Perubahan bentuk tubuh : tindakan invasif, seperti operasi, suntikan, daerah pemasangan infuse.

c. Perubahan struktur : sama dengan perubahan bentuk tubuh disrtai 
dengan pemasanagn alat di dalam tubuh.

d. Perubahan fungsi : berbagai penyakit yang dapat merubah system tubuh.

e. Keterbatasan : gerak, makan, kegiatan

f. Makna dan obyek yang sering kontak : penampilan dan dandan berubah, pemasangan alat pada tubuh klien ( infus, fraksi, respitor, suntik, pemeriksaan tanda vital, dll).

\subsubsection{Tanda dan Gejala}

Menurut Dalami tahun 2018, tanda dan gejala gangguan citra tubuh antara lain:

a. Menolak melihat dan menyentuh bagian tubuh yang berubah.

b. Tidak menerima perubahan yang telah terjadi/ akan terjadi.

c. Menolak penjelasan perubahan tubuh dan persepsi negative pada tubuh.

d. Preokupasi dengan bagian tubuh yang hilang.

e. Mengungkapkan keputusasaan.

f. Mengungkapkan ketakutan

\subsubsection{Stressor Yang Mempengaruhi Citra Tubuh}

a. Kehilangan bagian tubuh (mis., amputasi, mastektomi, histerektomi).

b. Kehilangan fungsi tubuh (mis., akibat stroke, cidera sumsum tulang belakang, penyakit neuromuskular, artritis, penurunan kemampuan mental dan sensori).

c. Disfigurement (mis., selama kehamilan, luka bakar berat, noda di wajah, kolostomi, trakeostomi). Ideal diri tidak realistis (mis., konfigurasi muskular yang tidak dapat dicapai).

\subsubsection{Tanda dan Gejala}

Tanda dan gejala gangguan citra tubuh antara lain:

1. Menolak melihat dan menyentuh bagian tubuh yang berubah.

2. Tidak menerima perubahan yang telah terjadi/ akan terjadi.

3. Menolak penjelasan perubahan tubuh dan persepsi negative pada tubuh. 
4. Preokupasi dengan bagian tubuh yang hilang.

5. Mengungkapkan keputusasaan.

6. Mengungkapkan ketakutan

\subsubsection{Stressor Yang Mempengaruhi Citra Tubuh}

a. Kehilangan bagian tubuh (mis., amputasi, mastektomi, histerektomi).

b. Kehilangan fungsi tubuh (mis., akibat stroke, cidera sumsum tulang belakang, penyakit neuromuskular, artritis, penurunan kemampuan mental dan sensori).

c. Disfigurement (mis., selama kehamilan, luka bakar berat, noda di wajah, kolostomi, trakeostomi).

\subsubsection{Terapi Keluarga}

Sebuah keluarga adalah sebuah sistem sosial yang alami, dimana seseorang menyusun aturan, peran, struktur kekuasaan, bentuk komunikasi, cara mendiskusikan pemecahan masalah sehingga dapat melaksanakan berbagai kegiatan dengan lebih efektif (Pardede, 2020)

\subsubsection{Terapi Hipnotis 5 Jari}

Pemberian terapi hipnotis lima jari ialah membantu pasien menurunkan stres tanpa adanya bantuan pharmakologi, memberikan dan meningkatkan pengalaman subjektif bahwa ketegangan fisiologis bisa direlaksasikan sehingga relaksasi akan menjadi kebiasaan berespon pada keadaankeadaan tertentu ketika otot tegang, menurunkan stres pada individu, mencegah manifestasi psikologis maupun fisiologis yang diakibatkan stress (Marbun, Pardede \& Perkasa, 2019).

\subsubsection{Gangguan Citra Tubuh pada Pasien Ca Mamae}

Gangguan citra tubuh adalah konfusi dalam gambaran mental fisik diri individu (NANDA, 2015). Masalah psikososial yang dapat dialami penyandang diabetes mellitus diantaranya meliputi gangguan konsep diri dan kecemasan. Gangguan konsep diri yang mungkin muncul diantaranya adalah gangguan citra tubuh. Citra tubuh membentuk persepsi seseorang 
tentang tubuh, baik secara internal maupun eksternal. Persepsi ini mencakup perasaan dan sikap yang ditujukan pada tubuh. Citra tubuh dipengaruhi oleh pandangan pribadi tentang karakteristik dan kemampuan fisik dan oleh persepsi dari pandangan orang lain (Potter \& Perry, 2015). Individu yang mengalami gangguan citra tubuh mungkin menyembunyikan atau tidak melihat atau menyentuh bagian tubuh yang strukturnya telah berubah akibat penyakit atau trauma. Beberapa individu dapat juga mengekspresikan perasaan tidak berdaya, putus asa, tidak mamp u megendalikan situasi, dan kerapuhan. Pasien yang dirawat di rumah sakit sangat mungkin mengalami perubahan citra tubuh, perubahan ukuran tubuh, berat badan yang turun akibat penyakit, perubahan bentuk tubuh, tindakan invasif, seperti operasi dan suntikan daerah pemasangan infus merupakan stresor yang bisa mengakibatkan ketidakpuasan terhadap bentuk tubuh yang memicu terjadinya gangguan citra tubuh. Makna objek sering kontak, penampilan berubah pemasangan alat pada tubuh klien (infus, respiratori, suntik, pemeriksaan tanda vital dan lain- lain) (Tjokroprawiro, 2011). Luka atau peradangan pada ekstremitas bawah atau kaki yang terjadi pada klien diabetes mellitus harus segera diobati, dirawat, bila terlambat mudah timbul ganggre diabetik (luka kehitaman karena sebagian jarinya mati dan membusuk, berbau tidak sedap atau busuk) pada akhirnya harus dipotong (amputasi), ganggren diabetik penderita mendapatkan insulin, antibiotik dosis tinggi, dan perawatan secara intensif (Hidayat, Musrifaul, Ullyah 2015).

Peran perawat dalam hal ini adalah menciptakan hubungan saling percaya dengan mendorong klien untuk membicarakan perasaan tentang dirinya, meningkatkan interaksi sosisal dngan cara membantu klien untuk menerima pertolongan dari orang lain, mendorong klien untuk melakukan aktivitas sosial, menerima keadaan dan lainnya (Hidayat, Musrifatul, Ullyah 2015).

\subsection{Konsep Ca Mammae}




\subsubsection{Pengertian Ca Mammae}

Carcinoma mammae yaitu sebuah keganasan yang sudah berasal dari sebuah sel kelenjar, saluran kelenjar dan pada jaringan dengan penunjang payudara. Ca mammae adalah sejenis tumor ganas yang sudah tumbuh di dalam jaringan sel di payudara. Kanker ini bisa mulai tumbuh yaitu di dalam kelenjar payudara seseorang, saluran payudara, di jaringan lemeak maupun ada di jaringan ikat pada sebuah payudara.(Medicastore, 2011). Ca mammae adalah yaitu suatu penyakit dari pertumbuhan sel, akibat dari adanya onkogen yang dapat juga menyebabkan sebuah sel normal akan menjadi sebuah sel kanker di dalamjaringan payudara seseorang (Karsono, 2010).

Ca mammae adalah yaitu dimana sekelompok sel yang tidak normal pada payudara seseorang yang terus tumbuh dan akan berlipat ganda. dan Pada akhirnya semua sel-sel ini terus akan menjadi bentuk sebuah benjolan di payudara. dan Jika sebuah benjolan kanker itu tidak bisa di buang atau tidak terkontrol,sel-sel kanker bisa menyebar (bermestastase) pada sebuah bagianbagian tubuh yang lain dan nantinya juga akan dapat mengakibatkan kematian. Metasase bisa juga terjadi yaitu pada sebuah kelenjar getah bening pada ketiak atau pun bisa juga yaitu diatas tulang belikat. Selain itu pada selsel kanker juga bisa bersarang di dalam tulang, bisa juga di paruparu, di hati kulit dan di bawah kulit dan kanker payudara merupakan sebuah penyakit yang bisa juga disebabkan karna terjadiya pembelahan sebuah sel-sel di dalam tubuh seseorang secara tidak teratur dan sehingga pada pertumbuhan sel juga tidak dapat dikendalikan dan dia akan tumbuh menjadi sebuah benjolan atau tumor (kanker) dari sel tersebut (Brunner \& Suddarth 2011). Ca mamae adalah yaitu sekelompok sel yang tidak normal pada sebuah payudara akan dan terus menerus tumbuh akan berupa ganda. Metastase bisa juga terjadi pada sebuah kelenjar getah bening atau (limfe) di ketiak ataupun bisa juga diatas tulang belikat. Dan Selain itu kanker juga akan bisa bersarang di dalam tulang, di paru-paru, di hati dan kulit (Erik, 2012). 


\subsubsection{Anatomi dan Fisiologi}

Jaringan payudara di bentuk oleh gladula yang sifatnya yaitu memproduksi sebuah air susu atau disebut juga dengan (lobulus) yaitu yang biasanya dialirkan ke arah putting atau disebut (nipple) yaitu melalui duktus. Struktur lainnya yaitu adalah sebuah jaringan lemak yang juga merupakan sebuah komponen yang terbesar, dan connective tissue, dengan pembuluh darah dan juga saluran yang beserta kelenjar limfatik. Maka Setiap dari payudara itu akan mengandung kira-kira 15-20 lobus yang dapat tersusun sirkuler. Pada Jaringan lemak (subcutaneous adipose tissue) yaitu yang membungkus satu lobus dapat memberikan sebuah bentuk dan ukuran dari payudara. Pada Tiap lobus itu juga terdiri dari beberapa lobules yang juga merupakan tempat untuk produksi air susu yang berfungsi sebagai respon dari suatu signal dan hormonal. Terdapat 3 macam jenis hormon yang bisa mempengaruhi dari payudara yaitu yakni estrogen, progesterone, dan prolactin., yang menyebabkan jaringan grandula payudara dan di uterus terus mengalami banyak perubahan selama dalam menjalani siklus menstruasi. dan Areola adalah hiperpigmentasi di sekitar nipple. Jaringan pada payudara juga dapat didukung oleh sebuah ligamentum suspensorim cooper. Dan sebuah Ligament ini akan terus berjalan sepanjang jalur parengkim dan juga dari fasia bagian dalam atau (deep fasia) dan akan melekat ke bagian dermis. Jika ligamentum inimemendek oleh karena infiltrasi sel kanker, akan menarik dermis yang memberikan gambaran skin dampling. Tidak ada otot dalam payudara, tapi otot terletak dibawah payudara dan menutup iga. Aliran darah ke arah kulit payudara itu tergantung juga pada pleksus subdermal,juga beserta yang terhubung dengan pembuluh darah yang sangat dalam atau bisa juga disebut dengan (deeper vessel) fingsinya yang akan mensuplai aliran darah ke parengkim payudara.

Suplai darah berasal dari:

1 perforator dari arteri mamaria interna.

2 Arteri torakalis lateralis.

3 Arteri torakodorsalis. 
4 Perforator arteri interkostalis.

\subsubsection{Arteri torakoakromialis}

Innervasi sensori berasal dari cabang anterolateral dan anteromedial nervus interkostalis T3-T5. Nervus supraklavikula atau yaitu yang berasal juga dari pleksus servikalis dan akan juga mensarafi bagian paling atas dan pada bagian lateral payudara. Para peneliti meyakini sensasi daerah nipple berasal dari cabang cutaneous lateral T4. Pembuluh darah dari limfatik dan dari kelenjar getah bening (KGB) dari glandula payudara dalah sangat penting. Pembuluh limfatik ini akan berjalanjalan di tepi bagian lateral di muskulus pektoralis mayor dan akan bersatu dengan kgb pectoral, yang akan selalu mengiringi pembuluh darah torakalis lateralis. Kelenjar getah bening menyebar ke muskulus seratus anterior dari sini aliran limfatik kemudian ke KGB aksila (mesenterika superior dan interpektoral). Jalur limfatik drainage lainnya adalah melalu pektoralis mayor dekat garis parasternal dan melalui intercostal space menuju KGB parasternal yang terletak sepanjang pembuluh darah mammaria interna.

\subsubsection{Etiologi}

\section{Genetika}

a. Adanya kecenderungan pada suatu keluarga tertentu yang lebih banyak mengalami gangguan kanker payudara daripada anggota keluarga sehat yang lain. b. Pada kembar suatu dari monozygote, dan juga terdapat kanker penyakit yang sama.

c. Tardapat kesamaan dan juga lateralisasi pada kanker buah dada dan juga pada keluarga terdekat dari orang yang menderita kanker payudara itu

d. Seseorang dengan klinifelter akan menapat kemungkinan lebih dari 66 kali dari pada seorang pria normal atau dari jumlah angka terjadinya $2 \%$

2. Hormon

a. Kanker payudara yang umumnya sering terjadi pada wanita, dan kejadian pada laki-laki akan kemungkinannya sangatlenih kecil.

b. Insiden ini akan jauh lebih tinggi terjadi pada wanita yang usianya diatas 
35 tahun.

c. Saat ini pengobatan dengan menggunakan terapi hormon yang hasilnya sangat memuaskan.

3. Virogen Yaitu yang Baru dilakukan percobaan atau experimennya pada seorang manusia dan hasilnya belum terbukti.

4. Makanan Yaitu yang Terutama makanan yang sangat banyak mengandung dan terkandung lemak.

5. Radiasi Daerah Dada Terapi ini Sudah cukup lama diketahui oleh orang, tspi radiasi juga akan dapat menyebabkan kejadian mutagen. Menurut (Tasripiyah,2012),

\subsubsection{Manifestasi Klinis}

Fase awal kanker seseorang payudara asimptomatika atau disebut juga (tanpa sedikitpun ada tanda dan gejalanya). Tanda awal yang paling sangat banyak terjadi yaitu adalah adanya sebuah benjolan atau adanya penebalan pada kulit payudara. Dan Kebanyakan 90\% ditemukan dari seorang wanita itu sendiri, dan akan tetapi ditemukan secara kebetulan saja, atau tidak dengan menggunakan atau tidak melakukan pemeriksaan pada payudara sendiri atau disebut (sadari) (Tasripiyah, 2012).

\subsubsection{Patofisiologi}

Sel-sel dri kanker itu dibentuk dari sebuah sel-sel yang normal di dalam suatu proses yang sangat rumit yang bisa disebut juga dengan transformasi, yang juga terdapat dari setiap insiasi dan promosi :

1. Fase insiasi Pada tahap pertama yaitu insiasi akan terjadi sebuah perubahan di dalam bahan yang genetic sel yang sering memancing sel itu menjadi sangat ganas. Perubahan yang ada di dalam bahan yang genetic sel ini sering disebabkan oleh salah satu agen yang bisadisebut karsinogen, yang juga bisa berupa bahan yang ber kimia virus, atau bisa juga radiasi/ (penyinaran) dari sinar matahari. Tetapi tidak juga semua sel yang memiliki kepekaan yang sama semuanya terhadap suatu karsinogen. Maka Kelainan genetic di dalam sel atau bahan kimia lainnya disebut dengan promotor, 
akan menyebabkan sel yang lebih rentan terhadap salah suatu karsinogen.dan juga Bahkan gangguan fisik yang sudah menahunpun juga bisa membuat sel menjadi akan lebih pekasekali untuk mengalami gangguan suatu keganasan.

2. Fase promosi Pada tahap kedua ini yaitu promosi, salah satu sel yang sudah mengalamifase insiasi akan bisa berubah unutk menjadi ganas. Sel ini yang belum mampu melewati tahap pertama insiasi maka tidak akan bisa terpengaruh pleh promosi. Karna itu diperlukan beberapa factor untuk terjdainya keganasan atau (gabungan dari semua sel yang sudah peka dan pada suatu karsinogen).

\subsection{Konsep Asuhan Keperawatan}

\subsubsection{Pengkajian}

\section{Faktor Predisposisi}

Terjadinya gangguan konsep citra tubuh juga dipengaruhi beberapa faktor predisposisi seperti faktor biologis, psikologis, sosial dan kultural:

\section{a. Kajian Biologis}

kondisi sakit fisik yang dapat mempengaruhi kerja hormon secara umum, yang dapat pula berdampak pada keseimbangan neurotransmiter di otak contoh kadar serotonin yang menurun dapat mengakibatkan klien mengalami depresi dan pada pasien gangguan citra tubuh kecendrungan berdampak pada harga diri rendah semakin besar karena klien lebih dikuasai oleh pikiranpikiran negatif dan tidak berdaya.

\section{b. Kajian Psikologis}

Berdasarkan faktor psikologis, gangguan citra tubuh sangat berhubungan dengan harga diri rendah dan kemampuan individu menjalankan peran dan fungsi. Hal-hal yang dapat mengakibatkan individu mengalami harga diri rendah meliputi penolakkan orang, harapan yang tidak realistis, tekanan teman sebaya, peran yang tidak sesuai dengan jenis kelamin dan peran 
dalam pekerjaan.

\section{c. Kajian Sosial}

Sosial status ekonomi sangat mempengaruhi proses terjadinya gangguan citra tubuh yang menuju harga diri rendah kronis, antara lain kemiskinan, tempat tinggal didaerah kumuh dan rawan, kultur sosial yang berubah misal ukuran keberhasilan individu.

\section{d. Kajian Kultural}

Tunutunan peran sosial kebudayaan sering meningkatkan kejadian terhadap penolakan pada klien dengan gangguan citra tubuh antara lain: wanita sudah harus memiliki tubuh yang sempurna, menikah jika umur mencapai dua puluhan, perubahan kultur kearah gaya hidup individualisme.

\section{Faktor Presipitasi}

Masalah khusus tentang konsep diri disebabkan oleh situasi yang dihadapi individu dan individu yang tidak mampu menyelesaikan masalah. Situasi atau stressor dapat mempengaruhi konsep diri dan komponennya :

a. Trauma seperti penganiayaan seksual secara verbal dan psikologis atau menyaksikan peristiwa yang mengancam kehidupan.

b. Ancaman terhadap sistem diri seseorang dapat membahayakan identitas, harga diri dan fungsi sosial yang terintegrasi seseorang.

\section{Perilaku}

Gangguan citra tubuh dapat diekspresikan secara langsung melalui perubahan fisiologi dan perilaku dan secara tidak langsung melalui timbulnya gejala atau mekanisme koping dalam upaya melawan rasa malu. Intensitas perilaku akan meningkat sejalan dengan peningkatan tingkat citra tubuh.

a. Respon Fisiologis Terhadap gangguan cutra tubuh 


\begin{tabular}{|c|c|}
\hline Sistem Tubuh & Respons \\
\hline Kardiovaskuler & $\begin{array}{l}\text { - Palpitasi. } \\
\text { - Jantung berdebar. } \\
\text { - Tekanan darah rendah dan denyut nadi menurun. } \\
\text { - Rasa mau pingsan. }\end{array}$ \\
\hline Pernafasan & $\begin{array}{l}\text { - } \\
\text { - } \text { Pernapas cepat. } \\
\text { - Rasa tertekan pada dada. } \\
\text { - Pembengkakan pada tenggorokan. } \\
\text { - Rasa tercekik. } \\
\text { - Terengah-engah. }\end{array}$ \\
\hline Neuromuskular & $\begin{array}{l}\text { - } \text { Peningkatan reflek. } \\
\text { - } \text { Reaksi kejutan. } \\
\text { - Insomnia. } \\
\text { - Ketakutan. } \\
\text { - Gelisah. } \\
\text { - Wajah tegang. } \\
\text { - Malu } \\
\text { - Kelemahan secara umum. } \\
\text { - Gerakan lambat. } \\
\text { - Gerakan yang janggal. }\end{array}$ \\
\hline Gastrointestinal & $\begin{array}{l}\text { - } \text { Kehilangan nafsu makan. } \\
\text { - } \text { Menolak makan. } \\
\text { - } \text { Perasaan dangkal. } \\
\text { - } \text { Rasa tidak nyaman pada abdominal. } \\
\text { - Rasa terbakar pada jantung. } \\
\text { - Nausea. } \\
\text { - } \text { Diare. }\end{array}$ \\
\hline Perkemihan & $\begin{array}{l}\text { - Tidak dapat menahan kencing. } \\
\text { - Sering kencing. }\end{array}$ \\
\hline Kulit & $\begin{array}{l}\text { - } \quad \text { Rasa terbakar pada mukosa. } \\
\text { - } \text { Berkeringat banyak pada telapak tangan. } \\
\text { - } \text { Perasaan panas atau dingin pada kulit. } \\
\text { - Mucat dan bekeringat diseluruh tubuh. }\end{array}$ \\
\hline
\end{tabular}

b. Respon Perilaku Kognitif

\begin{tabular}{|l|ll|}
\hline \multicolumn{1}{|c|}{ Sistem } & & \multicolumn{1}{c|}{ Respons } \\
\hline Perilaku & $\bullet$ & Gelisah. \\
& $\bullet$ & Ketegangan fisik. \\
\end{tabular}




\begin{tabular}{|c|c|}
\hline & $\begin{array}{l}\text { - Tremor. } \\
\text { - Gugup. } \\
\text { - } \text { Bicara cepat. } \\
\text { - Tidak ada koordinasi. } \\
\text { - Kecenderungan untuk celaka. } \\
\text { - Menarik diri. } \\
\text { - } \text { Menghindar. } \\
\text { - Terhambat melakukan aktifitas. }\end{array}$ \\
\hline \multirow[t]{2}{*}{ Kognitif } & $\begin{array}{l}\text { - } \text { Gangguan perhatian. } \\
\text { - Konsentrasi hilang. } \\
\text { - } \text { Pelupa. } \\
\text { - Salah tafsir. } \\
\text { - Adanya bloking pada pikiran. } \\
\text { - } \text { Menurunnya lahan persepsi. } \\
\text { - Kreatif dan produktif menurun. } \\
\text { - } \text { Bingung. }\end{array}$ \\
\hline & $\begin{array}{l}\text { - Khawatir yang berlebihan. } \\
\text { - Hilang menilai objektifitas. } \\
\text { - Takut akan kehilangan kendali. } \\
\text { - Takut yang berlebihan. }\end{array}$ \\
\hline Afektif & $\begin{array}{l}\text { - } \text { Mudah terganggu. } \\
\text { - Tidak sabar. } \\
\text { - Gelisah. } \\
\text { - Tegang. } \\
\text { - Nerveus. } \\
\text { - Ketakutan. } \\
\text { - Alarm. } \\
\text { - Tremor. } \\
\text { - Gugup. } \\
\text { - Gelisah. }\end{array}$ \\
\hline
\end{tabular}

4. Sumber Koping

Sumber koping tersebut sebagai modal ekonomok, kemampuan penyelesaian masalah, dukungan sosial dan keyakinan budaya dapat membantu seseorang mengintegrasikan pengalaman yang menimbulkan stress dan mengadopsi strategi koping yang berhasil.

5. Mekanisme Koping

Ketika mengalami gangguan citra tubuh individu menggunakan berbagai 
mekanisme koping untuk mencoba mengatasinya dan ketidakmampuan mengatasi citra tubuh secara konstruktif merupakan penyebab utama terjadinya perilaku patologis. Ansietas tingkat ringan sering ditanggulangi tanpa yang serius.

\subsubsection{Diagnosa Keperawatan}

Adapun diagnosa yang biasanya muncul adalah :

1. Gangguan Citra Tubuh

2. Koping Individu Tidak Efektif

3. Harga Diri Rendah

4. Ketidakberdayaan

5. Perubahan Proses Berfikir

\subsubsection{Intervensi Keperawatan}

\section{Gangguan citra tubuh}

Tujuan :

- Klien mampu mengenal bagian tubuh yang sehat dan yang terganggu atau sakit

- Klien mampu mengetahui cara mengatasi gangguan citra tubuh

- Klien mampu mengafirmasi bagian tubuh yang sehat

- Klien mampu melatih dan menggunakan bagian tubuh yang sehat

- Klien mampu merawat dan melatih bagian tubuh yang terganggu

- Klien mampu mengevaluasi manfaat yang telah dirasakan dari bagian tubuh yang terganggu

- Klien mampu mengevaluasi manfaat bagian tubuh yang masih sehat

- Klien mampu merasakan manfaat latihan pada bagian tubuh yang terganggu

Tindakan :

a. Kaji tanda dan gejala gangguan citra tubuh dan kemampuan klien mengatasinya.

b. Jelaskan tanda dan gejala, penyebab dan akibat gangguan citra 
tubuh

c. Diskusikan persepsi, perasaan, dan harapan klien terhadap citra tubuhnya

d. Menjelaskan perubahan-perubahan fisik yang terjadi pada ibu hamil

e. Motivasi klien untuk merawat dan meningkatkan citra tubuh seperti : menggunakan make up dan skincare untuk wajah yang berjerawat.

f. Motivasi klien untuk melakukan latihan meningkatkan citra tubuh sesuai jadwal dan beri pujian.

\section{Koping tidak efektif}

Tujuan :

- Klien mampu mengetahui perubahan kondisi kesehatan dan kemampuannya mengatasi perubahan

- Klien mampu mengetahui pengertian tanda dan gejala penyebab serta akibat dari ketidakefektifan koping

- Klien mampu mengetahui cara mengatasi ketidakefektifan koping

- Klien mampu mengatasi masalah secara bertahap

- Klien mampu menggunakan sumber/daya sistem pendukung dalam mengatasi masalah

- Klien mampu merasakan manfaat latihan yang dilakukan

- Klien mampu mengembangkan koping yang efektif klien mampu merasakan manfaat sistem pendukung

Tindakan :

a. Kaji tanda dan gejala ketidakefektifan koping

b. Jelaskan proses terjadinya ketidakefektifan koping

c. Diskusikan koping (upaya atau cara) mengatasi masalah pada masa lalu

d. Koping (upaya) yang berhasil dan tidak berhasil. Berikan pujian

e. Pemanfaatan sumber daya atau sistem pendukung dalam mengatasi masalah

f. Latihan menggunakan upaya menyelesaikan masalah saat ini 
dengan menggunakan cara lama yang berhasil atau cara baru.

- Buat daftar masalah yang dihadapi

- Buat daftar cara (lama dan baru) yang akan digunakan

- Pilih, latih, dan jadwalkan cara yang akan digunakan untuk masalah yang dihadapi

- Evaluasi hasil jika berhasil dibudidayakan jika kurang berhasil dipilih cara lain pada daftar cara nomor kedua

g. Latih menggunakan sistem pendukung yang teratur

h. Beri motivasi dan pujian atas keberhasilan klien mengatasi masalah

\section{Harga Diri Rendah}

Tujuan :

- Bina hubungan saling percaya dengan menggunakan komunikasi yang terapeutik

- Klien mampu mengidentifikasi aspek positif dan kemampuan yang di miliki klien, keluarga dan lingkungan

- Klien mampu menilai kemampuan yang dimiliki untuk dilaksanakan

- Membantu klien memilih kegiatan yang akan dilatih sesuai dengan kemampuan

- Melatih klien kegiatan yang dipilih sesuai rencana yang dibuat sesuai kemampuan klien

\subsubsection{Implementasi keperawatan}

Merupakan inisiatif dari rencana tindakan untuk mencapai tujuan yang spesifik. Tahap pelaksanaan dimulai dimulai setelah rencana tindakan disusun dan ditujukan pada nursing orders untuk membantu klien mencapai tujuan yang diharapkan. Oleh karena itu rencana tindakan yang spesifik dilaksanakan untuk memodifikasi faktor-faktor yang mempengaruhi masalah kesehatan klien (Stuart, Keliat \& Pasaribu, 2016)

Adapun tahap-tahap dalam tindakan keperawatan adalah sebagai berikut

Tahap 1: persiapan Tahap awal tindakan keperawatan ini menuntut 
perawat untuk mengevaluasi yang diindentifikasi pada tahap perencanaan.

Tahap 2: intervensi Focus tahap pelaksanaan tindakan perawatan adalah kegiatan dan pelaksanaan tindakan dari perencanaan untuk memenuhi kebutuhan fisik dan emosional. Pendekatan tindakan keperawatan meliputi tindakan: independen, dependen, dan interdependen.

Tahap 3: dokumentasi Pelaksanaan tindakan keperawatan harus diikuti oleh pencatatan yang lengkap dan akurat terhadap suatu kejadian dalam proses keperawatan.

\subsubsection{Evaluasi}

Keberhasilan tindakan keperawatan. Keberhasilan proses dapat dilihat dengan jalan membandingkan antara proses dengan pedoman/rencana proses tersebut. Perencanaan evaluasi memuat criteria keberhasilan proses dan Sedangkan keberhasilan tindakan dapat dilihat dengan membandingkan antara tingkat kemandirian pasien dalam kehidupan sehari-hari dan tingkat kemajuan kesehatan pasien dengan tujuan yang telah di rumuskan sebelumnya. Sasaran evaluasi adalah sebagai berikut:

1) Proses asuhan keperawatan, berdasarkan criteria/ rencana yang telah disusun.

2) Hasil tindakan keperawatan, berdasarkan criteria keberhasilan yang telah di rumuskan dalam rencana evaluasi.

Hasil evaluasi Terdapat 3 kemungkinan hasil evaluasi yaitu :

1) Tujuan tercapai, apabila pasien telah menunjukan perbaikan/ kemajuan sesuai dengan criteria yang telah di tetapkan.

2) Tujuan tercapai sebagian, apabila tujuan itu tidak tercapai secara maksimal, sehingga perlu di cari penyebab dan cara mengatasinya.

3) Tujuan tidak tercapai, apabila pasien tidak menunjukan perubahan/kemajuan sama sekali bahkan timbul masalah baru.dalam hal ini perawat perlu untuk mengkaji secara lebih mendalam apakah terdapat data, analisis, diagnosa, tindakan, dan faktor-faktor lain yang tidak sesuai yang menjadi penyebab tidak tercapainya tujuan. 
Setelah seorang perawat melakukan seluruh proses keperawatan dari pengkajian sampai dengan evaluasi kepada pasien, seluruh tindakannya harus di dokumentasikan dengan benar dalam dokumentasi keperawatan (Stuart, Keliat \& Pasaribu, 2016). 
BAB 3

TINJAUAN KASUS

\subsection{PENGKAJIAN KEPERAWATAN}

\begin{tabular}{|l|l|}
\hline Nama : Ny .M & Kondisi saat MRS: \\
Usia : 25 tahun & \\
Tahun no reg : - & Kondisi saat ini : \\
Ruangan : - & M mengeluh badannya terasa lemas, nyeri pada bagian bekas \\
Tgl masuk rs: - & operasi, luka yang lama sembuh, malu dengan kondisi tubuh yang \\
Tgl pengkajian : 01 oktober 2021 & tidak sempurna lagi sehingga Ny.M tidak mampu melakukan \\
Alamat : Jalan Rengas Pulau Kec. Medan & aktivitas seperti biasanya, hingga membuat Ny. A takut dan \\
Marelan & gelisah dan tidak dapat melakukan aktifitasnya \\
& \\
& \\
\end{tabular}

\subsubsection{FAKTOR PREDISPOSISI DAN FAKTOR PRESIPITASI}

\begin{tabular}{|l|c|l|l|}
\hline \multirow{2}{*}{ FAKTOR PREDISPOSISI } & \multicolumn{2}{|c|}{ Origin } & Number - Timing \\
\cline { 2 - 4 } & \multicolumn{1}{|c|}{ Nature } & $\begin{array}{l}\text { Sejak 1 minggu yang } \\
\text { lalu }\end{array}$ & Ca Mammae \\
\hline Biologi & dan lemas, nyeri pada & Internal & \\
\hline
\end{tabular}




\begin{tabular}{|c|c|c|c|c|}
\hline $\begin{array}{l}\text { 1. Ca Mammae } \\
\text { 2. Ny. M menderita Ca Mammae } 2 \text { tahun yang } \\
\text { lalu } \\
\text { 3. Ny. M sering mengkonsumsi makanan Junk } \\
\text { Food } \\
\text { 4. Ny. M tidak rutin check up kepelayanan } \\
\text { kesehatan }\end{array}$ & $\begin{array}{l}\text { bagian bekas operasi, } \\
\text { luka yang lama } \\
\text { sembuh, teraba kasar } \\
\text { pada kulit }\end{array}$ & & & \\
\hline \multirow[t]{2}{*}{ FAKTOR PREDISPOSISI } & \multicolumn{3}{|c|}{ FAKTOR PRESIPITASI } & \multirow[t]{2}{*}{ STRESSOR } \\
\hline & Nature & Origin & Number - Timing & \\
\hline $\begin{array}{l}\text { Psikologi } \\
\text { 1. Ny. M memiliki kepribadia yang terbuka setiap ada } \\
\text { masalah akan dibicarakan dengan orang tuanya } \\
\text { 2. Ny. M merasa malu dengan kondisi tubuh yang tidak } \\
\text { sempurna lagi ,luka lama sembuh }\end{array}$ & $\begin{array}{l}\text { - Takut, Gelisa, } \\
\text { Malu, } \\
\text { Khawatir } \\
\text { - Sering } \\
\text { kepikiran } \\
\text { penyakitnya }\end{array}$ & Internal & $\begin{array}{l}\text { Sejak } 1 \text { minggu yang } \\
\text { lalu }\end{array}$ & $\begin{array}{l}\text { Gangguan citra } \\
\text { tubuh }\end{array}$ \\
\hline
\end{tabular}




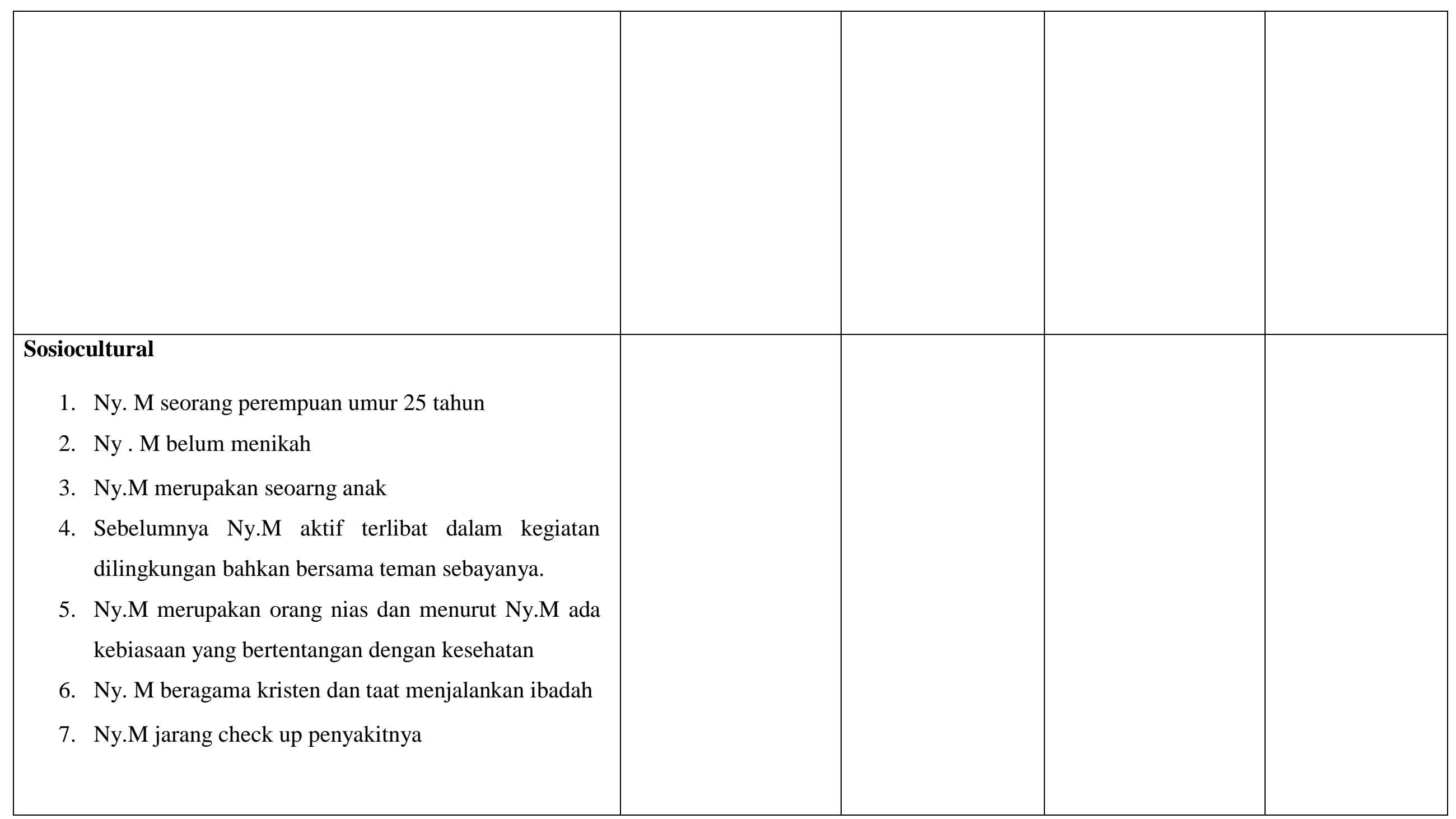




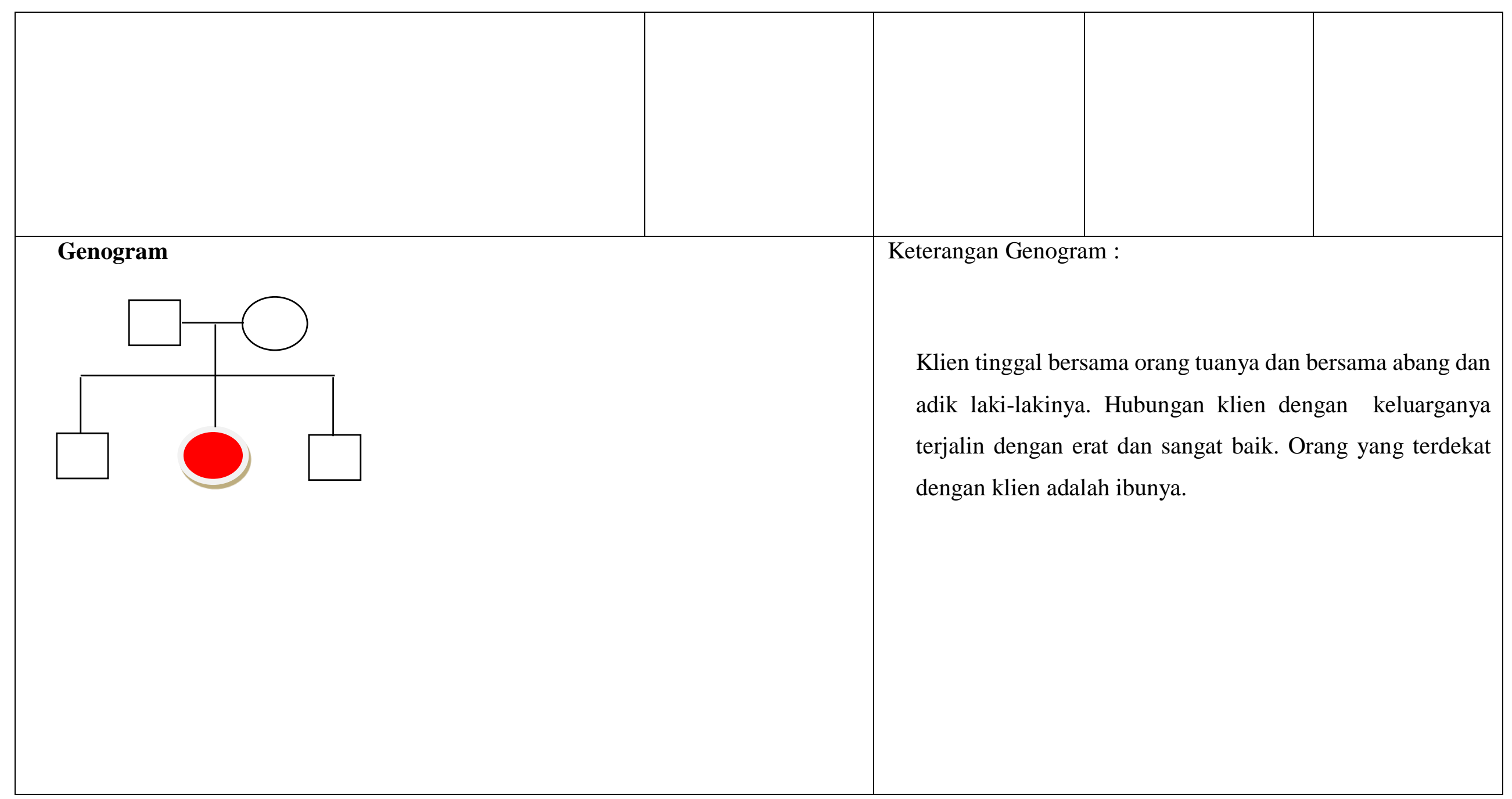




\subsubsection{PENILAIAN (RESPON) TERHADAP STRESSOR}

\begin{tabular}{|c|c|c|c|c|c|c|}
\hline STRESSOR & KOGNITIF & AFEKTIF & FISIOLOGIS & PERILAKU & SOSIAL & $\begin{array}{c}\text { DIAGNOSA } \\
\text { KEPERAWA } \\
\text { TAN }\end{array}$ \\
\hline $\begin{array}{l}\text { BIOLOGIS } \\
\text { - Ca Mammae }\end{array}$ & $\begin{array}{l}\text { - Menurut } \\
\text { Ny.M } \\
\text { penyakit } \\
\mathrm{Ca} \\
\text { Mammae } \\
\text { diakibatka } \\
\text { n karena } \\
\text { kebiasaan } \\
\text { mengkons } \\
\text { umsi } \\
\text { junkfood } \\
\text { - Mengang } \\
\text { gap }\end{array}$ & $\begin{array}{l}\text { - Ny.M } \\
\text { merasa } \\
\text { sedih } \\
\text {,malu dan } \\
\text { menolak } \\
\text { dengan } \\
\text { kondisi } \\
\text { yang } \\
\text { dialami } \\
\text { pada } \\
\text { tubuhnya } \\
\text { saat ini }\end{array}$ & $\begin{array}{ll}\text { - } & \text { nyeri } \\
\text { - } & \text { Sulit tidur } \\
\text { - } & \text { Tidak } \\
\text { nafsu } \\
\text { makan } \\
\text { - } \text { Turgor } \\
\text { kulit } \\
\text { teraba } \\
\text { kasar } \\
\text { - Ny.M } \\
\text { tampak } \\
\text { lemas } \\
\text { - Pemerik } \\
\text { saan } \\
\text { TTV } \\
\text { TD: } 90 / 80 \\
\text { mmhg } \\
\text { N : } 88 \text { x / } \\
\text { menit } \\
\text { P : } 22 \times \text { x } \\
\text { menit }\end{array}$ & $\begin{array}{l}\text { - Ny.M } \\
\text { jarang } \\
\text { kontrol } \\
\text { ke rumah } \\
\text { sakit } \\
\text { - Ekspres } \\
\text { i muka } \\
\text { malu } \\
\text { - Ny.M } \\
\text { tampak } \\
\text { lemas dan } \\
\text { takut }\end{array}$ & $\begin{array}{l}\text { - Pasien } \\
\text { mendatangi } \\
\text { dan } \\
\text { menggunak } \\
\text { a n fasilitas } \\
\text { kesehatan } \\
\text { yang ada } \\
\text { untuk } \\
\text { mencari } \\
\text { pengobatan } \\
\text { terhadap } \\
\text { masalah } \\
\text { yang }\end{array}$ & $\begin{array}{l}\text { Gangguan } \\
\text { Citra Tubuh }\end{array}$ \\
\hline
\end{tabular}




\begin{tabular}{|c|c|c|c|c|c|c|}
\hline & $\begin{array}{l}\text { penyakit } \\
\text { yang } \\
\text { diderita } \\
\text { sangat } \\
\text { serius } \\
\text { - Tidak } \\
\text { tahu apa } \\
\text { yang } \\
\text { harus } \\
\text { dilakukan } \\
\text { untuk } \\
\text { penyakitn } \\
\text { ya }\end{array}$ & & $\mathrm{S}: 37^{0} \mathrm{C}$ & & $\begin{array}{l}\text { dihadapi } \\
\text { saat ini }\end{array}$ & \\
\hline $\begin{array}{l}\text { PSIKOLOGIS } \\
\text { - Sedih, takut, } \\
\text { menolak, gelisa, } \\
\text { malu, dan } \\
\text { bingung dengan } \\
\text { kondisi } \\
\text { penyakit,pengob }\end{array}$ & $\begin{array}{l}\text { - Klien } \\
\text { memikirkan } \\
\text { bagaimana } \\
\text { jika tidak } \\
\text { ada yang } \\
\text { ingin }\end{array}$ & $\begin{array}{l}\text { - Merasa } \\
\text { malu } \\
\text { dan } \\
\text { menolak } \\
\text { mempu } \\
\text { nyai } \\
\text { tubuhny }\end{array}$ & $\begin{array}{l}\text { - } \text { nyeri } \\
\text { - Sulit tidur } \\
\text { - } \text { Tidak } \\
\text { nafsu } \\
\text { makan } \\
\text { - } \text { Turgor } \\
\text { kulit } \\
\text { teraba }\end{array}$ & $\begin{array}{l}\text { - Tampak } \\
\text { takut dan } \\
\text { merasa } \\
\text { tidak } \\
\text { berharga, } \\
\text { tidak } \\
\text { tenang } \\
\text { - Ny.M }\end{array}$ & $\begin{array}{l}\text { - Hubunga } \\
\text { n Ny.M } \\
\text { dengan } \\
\text { keluarga } \\
\text { baik } \\
\text { - Ny.M } \\
\text { kurang }\end{array}$ & $\begin{array}{l}\text { - } \begin{array}{l}\text { Gangguan } \\
\text { citra } \\
\text { tubuh }\end{array} \\
\text { - Harga diri } \\
\text { rendah }\end{array}$ \\
\hline
\end{tabular}




\begin{tabular}{|c|c|c|c|c|c|c|}
\hline $\begin{array}{l}\text { atan, juga } \\
\text { perawatannya }\end{array}$ & $\begin{array}{l}\text { menikah } \\
\text { dengannya } \\
\text { - Ny.M tahu } \\
\text { bahwa } \\
\text { badannya } \\
\text { menjadi } \\
\text { lemah, nyeri } \\
\text { dan luka } \\
\text { yang lama } \\
\text { sembuh } \\
\text { merupakan } \\
\text { dampak dari } \\
\text { penyakit } \\
\text { yang } \\
\text { diderita }\end{array}$ & $\begin{array}{l}\text { a yang } \\
\text { saat ini } \\
\text { - Takut } \\
\text { dibicara } \\
\text { kan oleh } \\
\text { orang } \\
\text { sekitarn } \\
\text { ya }\end{array}$ & $\begin{array}{ll}\text { kasar } \\
\text { - } & \text { Ny.M } \\
\text { tampak } \\
\text { lemas } \\
\text { - } \text { Pemerik } \\
\text { saan } \\
\text { TTV } \\
\text { TD: } 90 / 80 \\
\text { mmhg } \\
\mathrm{N}: 88 \mathrm{x} / \\
\text { menit } \\
\mathrm{P}: 22 \times \text { / } \\
\text { menit } \\
\mathrm{S}: 37{ }^{0} \mathrm{C}\end{array}$ & $\begin{array}{l}\text { tampak } \\
\text { gelisah } \\
\text { - Ny.M } \\
\text { tampak } \\
\text { pasif dalam } \\
\text { menerima } \\
\text { perawatan } \\
\text { - Ny.A } \\
\text { menunduk } \\
\text { dan malu } \\
\text { saat } \\
\text { bercerita }\end{array}$ & $\begin{array}{l}\text { bersosiali } \\
\text { sasi } \\
\text { dengan } \\
\text { keluarga }\end{array}$ & \\
\hline $\begin{array}{l}\text { SOSIAL BUDAYA } \\
\text { - Klien jarang } \\
\text { melakukan/men }\end{array}$ & $\begin{array}{l}\text { - } \text { merasa } \\
\text { malu dan }\end{array}$ & $\begin{array}{l}\text { - Merasa } \\
\text { khawatir }\end{array}$ & $\begin{array}{ll}\text { - } & \text { nyeri } \\
\text { - } & \text { Sulit tidur } \\
\text { - } & \text { Tidak } \\
& \text { nafsu }\end{array}$ & $\begin{array}{l}\text { - Kontak mata } \\
\text { ada tapi tidak } \\
\text { bertahan } \\
\text { lama }\end{array}$ & $\begin{array}{l}\text { - Hubung } \\
\text { an } \\
\text { Ny.M } \\
\text { dengan }\end{array}$ & $\begin{array}{l}\text { - Penampila } \\
\text { n peran }\end{array}$ \\
\hline
\end{tabular}




\begin{tabular}{|c|c|c|c|c|c|c|}
\hline $\begin{array}{l}\text { gikuti kegiatan } \\
\text { masyarakat } \\
\text { - Tidak ada } \\
\text { sosialisasi } \\
\text { dengan } \\
\text { masyarakat }\end{array}$ & $\begin{array}{l}\text { mempunyai } \\
\text { hambatan } \\
\text { dalam } \\
\text { bersosialisa } \\
\text { si }\end{array}$ & $\begin{array}{l}\text { dan sedih } \\
\text { kepada } \\
\text { orangtuan } \\
\text { ya yang } \\
\text { merawatn } \\
\text { ya setiap } \\
\text { hari }\end{array}$ & $\begin{array}{ll}\text { - } & \text { Turgan } \\
\text { kulit } \\
\text { teraba } \\
\text { kasar } \\
\text { - } & \text { Ny.M } \\
& \text { tampak } \\
& \text { lemas } \\
\text { - } & \end{array}$ & $\begin{array}{ll}\text { - } & \text { Volume } \\
\text { suara } \\
\text { mengecil } \\
\text { - Ny.M } \\
\text { tampak } \\
\text { gelisah,taku } \\
\text { t,dan malu }\end{array}$ & $\begin{array}{l}\text { keluarg } \\
\text { a baik } \\
\text { - Hubung } \\
\text { an } \\
\text { Ny.M } \\
\text { dengan } \\
\text { petugas } \\
\text { kesehat } \\
\text { an baik } \\
\text { - Ny.M } \\
\text { tetap } \\
\text { mengik } \\
\text { uti } \\
\text { progra } \\
\text { m } \\
\text { pengob } \\
\text { atan }\end{array}$ & $\begin{array}{l}\text { tidak } \\
\text { efektif }\end{array}$ \\
\hline
\end{tabular}




\subsubsection{SUMBER KOPING}

\begin{tabular}{|c|c|c|c|c|c|}
\hline $\begin{array}{c}\text { DIAGNOSA } \\
\text { KEPERAWATAN }\end{array}$ & PERSONAL ABILITY & SOSIAL SUPPORT & $\begin{array}{c}\text { MATERIAL } \\
\text { ASSET } \\
\end{array}$ & BELIEF & TERAPI \\
\hline $\begin{array}{l}\text { Gangguan citra } \\
\text { tubuh }\end{array}$ & $\begin{array}{l}\text { Klien mengakui tidak dapat } \\
\text { menerima keadan dirinya dengan } \\
\text { perubahan pada tubuhnya }\end{array}$ & $\begin{array}{l}\text { Keluarga memberikan } \\
\text { dukungan yang baik } \\
\text { kepada klien }\end{array}$ & $\begin{array}{l}\text { - Sosial } \\
\text { ekonomi } \\
\text { Ny.M } \\
\text { menengah } \\
\text { Pengobatan } \\
\text { ditanggung } \\
\text { BPJS } \\
\text { - Menggunakan } \\
\text { dana pribadi } \\
\text { saat berobat } \\
\text { ketika sakit }\end{array}$ & $\begin{array}{l}\text { Klien yakin } \\
\text { dengan } \\
\text { diajarkan terapi } \\
\text { bisa mengurangi } \\
\text { rasa takut dan } \\
\text { malu yang } \\
\text { dirasakan } \\
\\
\text { Klien yakin } \\
\text { dengan bantuan } \\
\text { dan dukungan } \\
\text { dari orang } \\
\text { sekitar dia } \\
\text { mampu }\end{array}$ & $\begin{array}{l}\text { Terapi } \\
\text { generalis: } \\
\text { gangguan } \\
\text { citra tubuh } \\
\text { Terapi } \\
\text { spesialis: } \\
\text { Terapi } \\
\text { kognitif }\end{array}$ \\
\hline
\end{tabular}




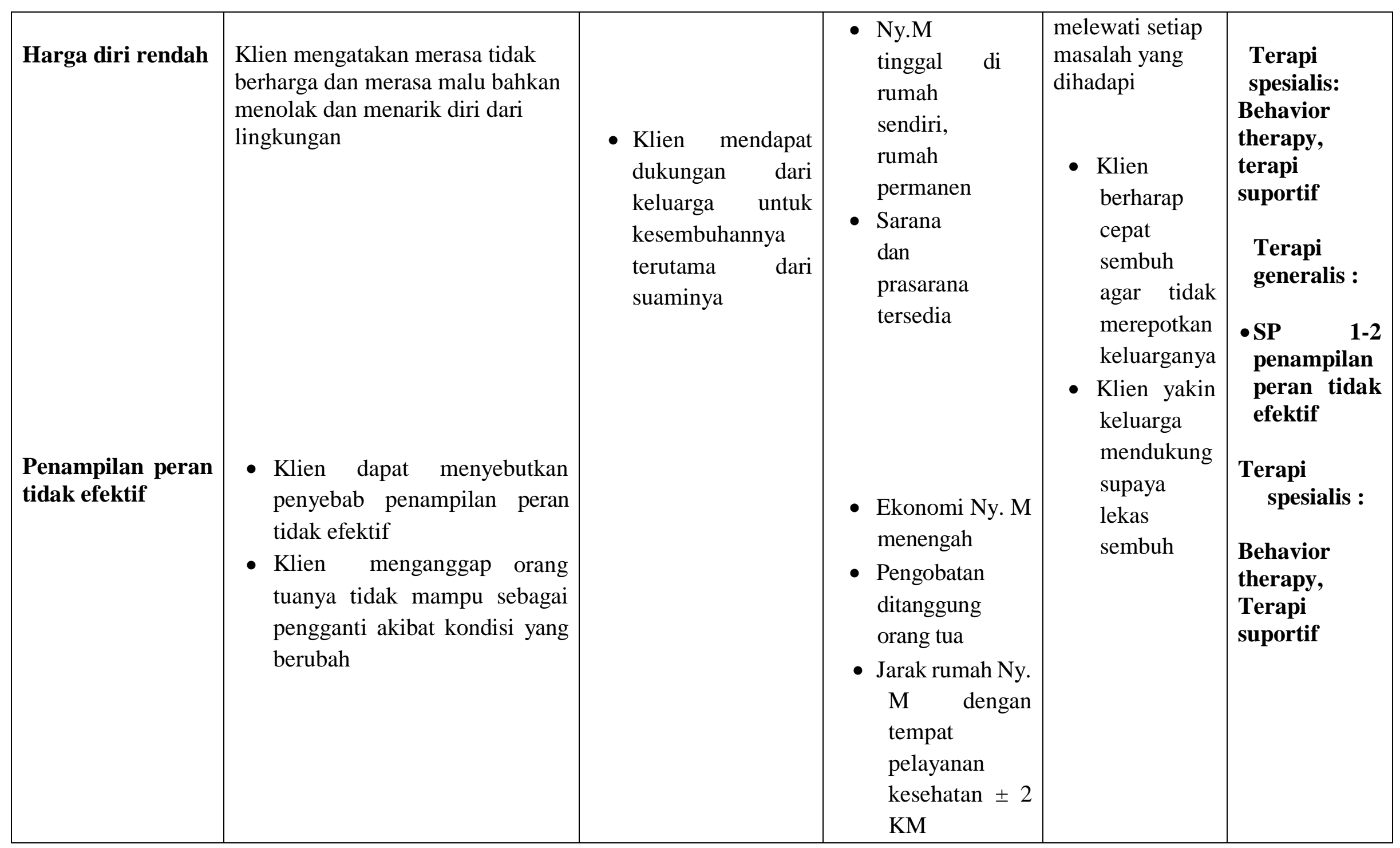




\subsubsection{MEKANISME KOPING}

\begin{tabular}{|l|l|}
\hline HAL YANG DILAKUKAN & ANALISA \\
\hline - Klien mengatakan bila ada masalah, maka ia akan membicarakan & $\bullet$ Konstruktif: \\
dengan suami dan keluarga untuk mencari jalan keluarnya & Klien mengatakan bila ada masalah, maka ia akan \\
- Bila sakit klien berobat ke pelayanan kesehatan & $\begin{array}{l}\text { membicarakan dengan keluarga untuk mencari jalan } \\
\text { - Klien taat menjalankan ibadah sesuai dengan keyakinannya }\end{array}$ \\
Klien selalu berdoa kepada TYM untuk kesembuhan dan & $\begin{array}{l}\text { Bila sakit klien berobat ke pelayanan kesehatan } \\
\text { Klien taat menjalankan ibadah sesuai dengan } \\
\text { kesehatan janinnya }\end{array}$ \\
keyakinannya
\end{tabular}


- Destruktif : - 


\subsubsection{STATUS MENTAL}

\begin{tabular}{|l|l|}
\hline 1. Penampilan & Rapi dan bersih \\
\hline 2. Pembicaraan & Menceritakan semua yang dialaminya dengan ekspresi wajah malu dan gelisa \\
\hline 3. Aktivitas motorik & Mampu berinteraksi \\
\hline $\begin{array}{l}\text { 4. } \text { Interaksi selama } \\
\text { wawancara }\end{array}$ & Ada kontak mata saat wewancara \\
\hline 5. Alam perasaan & Klien merasa malu dan takut dibicarakan oleh orang lain \\
\hline 6. Afek & Sesuai dengan emosi \\
\hline 7. Persepsi & Tidak ada gangguan \\
\hline 8. Isi pikir & Tidak ada gangguan isi pikir \\
\hline 9. Proses pikir & Tidak ada gangguan proses pikir \\
\hline 10. Tingkat kesadaran & Normal \\
\hline 11. Daya ingat & Normal \\
\hline 12. Kemampuan berhitung & Tidak ada gangguan dalam berhitung \\
\hline 13. Penilaian & Klien mampu mengambil keputusan untuk dirinya sendiri \\
\hline 14. Daya tilik diri & $\begin{array}{l}\text { Klien menyadari memang tidak dapat menerima kaadaan dirinya dengan } \\
\text { perubahan pada tubuhnya }\end{array}$ \\
\hline
\end{tabular}

Kesimpulan : Mental Status Examination (MSE) tidak ada masalah gangguan jiwa, gangguan Ny.M lebih kepada Gangguan Mental Emosional (GME/Psikososial) 


\subsection{DIAGNOSA DAN TERAPI}

\begin{tabular}{|c|c|}
\hline $\begin{array}{l}\text { DIAGNOSA KEPERAWATAN DAN TERAPI } \\
\text { KEPERAWATAN }\end{array}$ & DIAGNOSA MEDISDAN TERAPI MEDIS \\
\hline $\begin{array}{l}\text { 1. Gangguan citra tubuh } \\
\text { - Kaji tanda dan gejala gangguan citra tubuh dan } \\
\text { kemampuan klien mengatasinya. } \\
\text { - Jelaskan tanda dan gejala, penyebab dan akibat gangguan } \\
\text { citra tubuh } \\
\text { - Diskusikan persepsi, perasaan, dan harapan klien } \\
\text { terhadap citra tubuhnya } \\
\text { - Menjelaskan perubahan-perubahan fisik yang terjadi } \\
\text { pada ibu hamil } \\
\text { - Motivasi klien untuk merawat dan meningkatkan citra } \\
\text { tubuh seperti : menggunakan make up dan skincare untuk } \\
\text { wajah yang berjerawat. } \\
\text { - Motivasi klien untuk melakukan latihan meningkatkan } \\
\text { citra tubuh sesuai jadwal dan beri pujian. } \\
\text { 2. Harga Diri Rendah } \\
\text { Terapi Hipnotis } 5 \text { jari }\end{array}$ & Ca Mammae \\
\hline
\end{tabular}




\section{Penampilan peran tidak efektif}

Terapi perilaku

\subsection{IMPLEMENTASI TINDAKAN KPERAWATAN DAN EVALUASI}

\begin{tabular}{|c|c|}
\hline IMPLEMENTASI TINDAKAN KEPERAWATAN & EVALUASI (SOAP \\
\hline $\begin{array}{l}\text { Tanggal : } 02 \text { Oktober } 2021 \\
\text { Jam : } 10.00 \text { wib } \\
\text { a. Motivasi klien untuk merawat dan meningkatkan citra tubuh seperti : } \\
\quad \text { menggunakan make up dan skincare untuk wajah yang berjerawat. } \\
\text { - Teknik relaksasi napas dalam } \\
\text { - Distraksi : bercakap-cakap hal positif } \\
\text { - Hipnotis } 5 \text { jari fokus padahal-hal yang positif } \\
\text { b. Bantu klien melakukan latihan sesuai dengan jadwal kegiatan. }\end{array}$ & $\begin{array}{l}\text { S: klien mampu mengungkapkan presepsi tentang } \\
\text { citra tubuhnya dulu dan saat ini } \\
\text { O:pasien tampak tenang dan mampu } \\
\text { mengungkapkan perasaan tentang citra tubuhnya } \\
\text { dan harapan tentang citra tubuhnya saat ini } \\
\text { A:Gangguan Citra Tubuh (-) } \\
\text { P Klien: pasien melakukan terapi yang diajarkan } \\
\text { Pperwat : evaluasi terapi ke sesi } 1 \text { selesai dan } \\
\text { menyiapkan terapi selanjutnya } \\
\text { S: klien mampu mengungkapkan penyebab serta } \\
\text { proses terjadinya gangguan citra tubuhnya dulu } \\
\text { dan saat ini } \\
\text { O:pasien tampak tenang dan mampu menerima } \\
\text { perasaan tentang citra tubuhnya } \\
\text { A:Gangguan Citra Tubuh (-) } \\
\text { P Klien: pasien melakukan terapi yang diajarkan }\end{array}$ \\
\hline
\end{tabular}




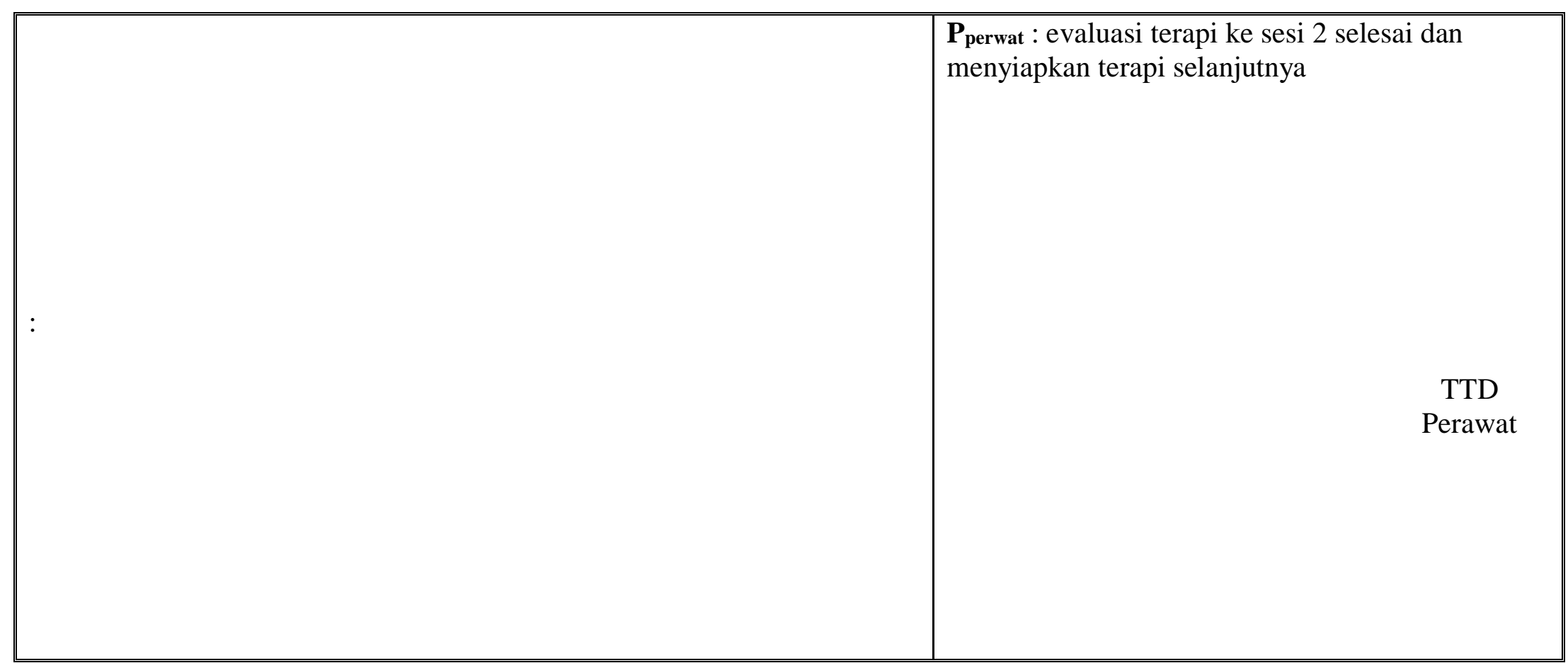




\section{Tanggal : 04 Oktober 2021}

Jam : $10.00 \mathrm{wib}$

a. Kaji tanda dan gejala ketidakefektifan koping

b. Jelaskan proses terjadinya ketidakefektifan koping

c. Diskusikan koping (upaya atau cara) mengatasi masalah pada masa lalu

d. Koping (upaya) yang berhasil dan tidak berhasil. Berikan pujian

Tanggal : 05 Oktober 2021

Jam : $14.00 \mathrm{wib}$

a. Mengkaji klien untuk mengenali dan mendiskusikan pemikiran untuk sadar akan hal negative tentang diri

b. Membantu klien untuk mengidentifikasi sumber motivasi

c. Bantu klien melakukan terapi kognitif perilaku

d. Bantu klien melakukan latihan sesuai jadwal kegiatan
S :

- Klien mengatakan ia mampu mengindentifikasi situasi yang mencetus harga diri rendah

- Klien mengatakan sudah bisa melakukan teknik tarik napas dalam

- Klien mengatakan sudah bisa menggunakan make up

- Klien mengatakan sudah bisa melakukan teknik hipnotis 5 jari

O :

- Klien tampak rileks dan tidak gelisah lagi

- Klien mampu meningkatkan citra tubuh dengan menggunakan make up

- Klien mampu melakukan distraksi

- Klien mampu melakukan hipnotis 5 jari

A : Harga Diri Rendah (-)

$\mathbf{P}$ :

- Bantu klien melakukan latihan sesuai dengan jadwal kegiatan

- Terapi Perilaku 


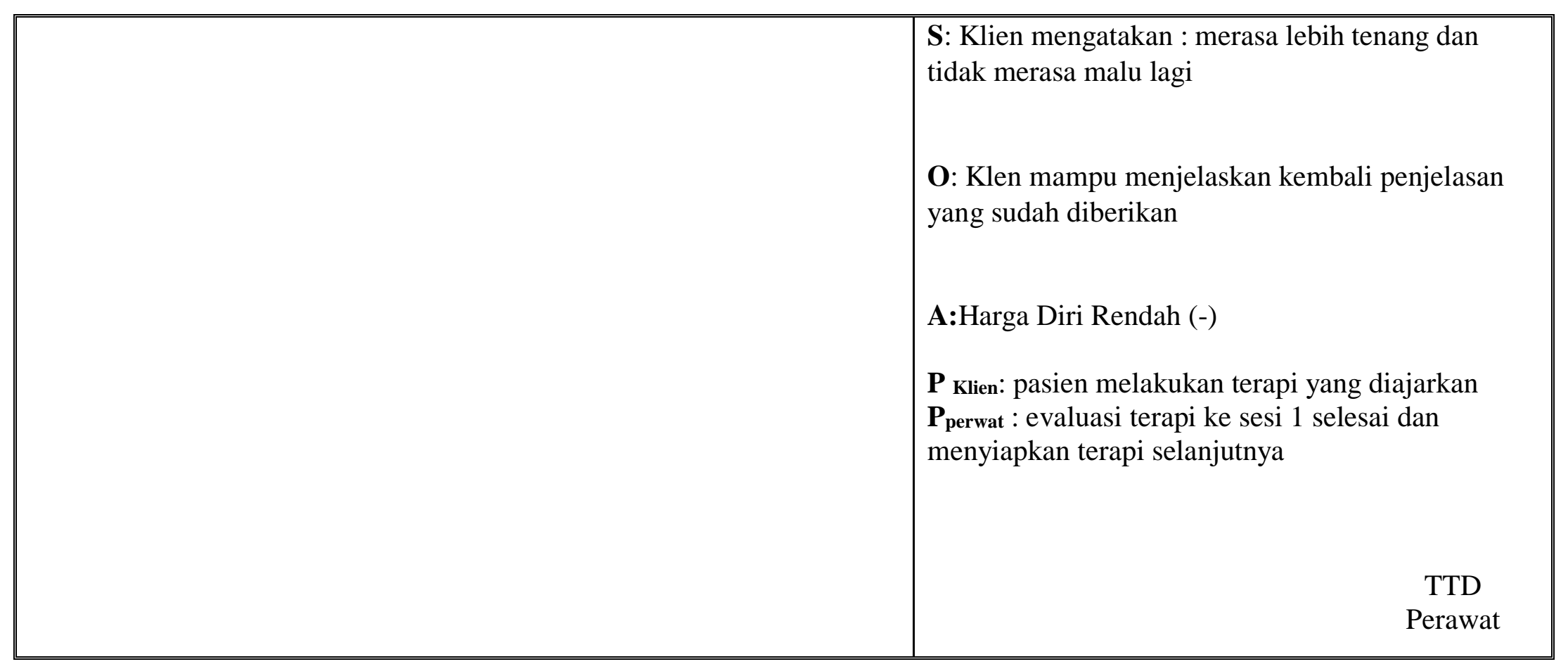




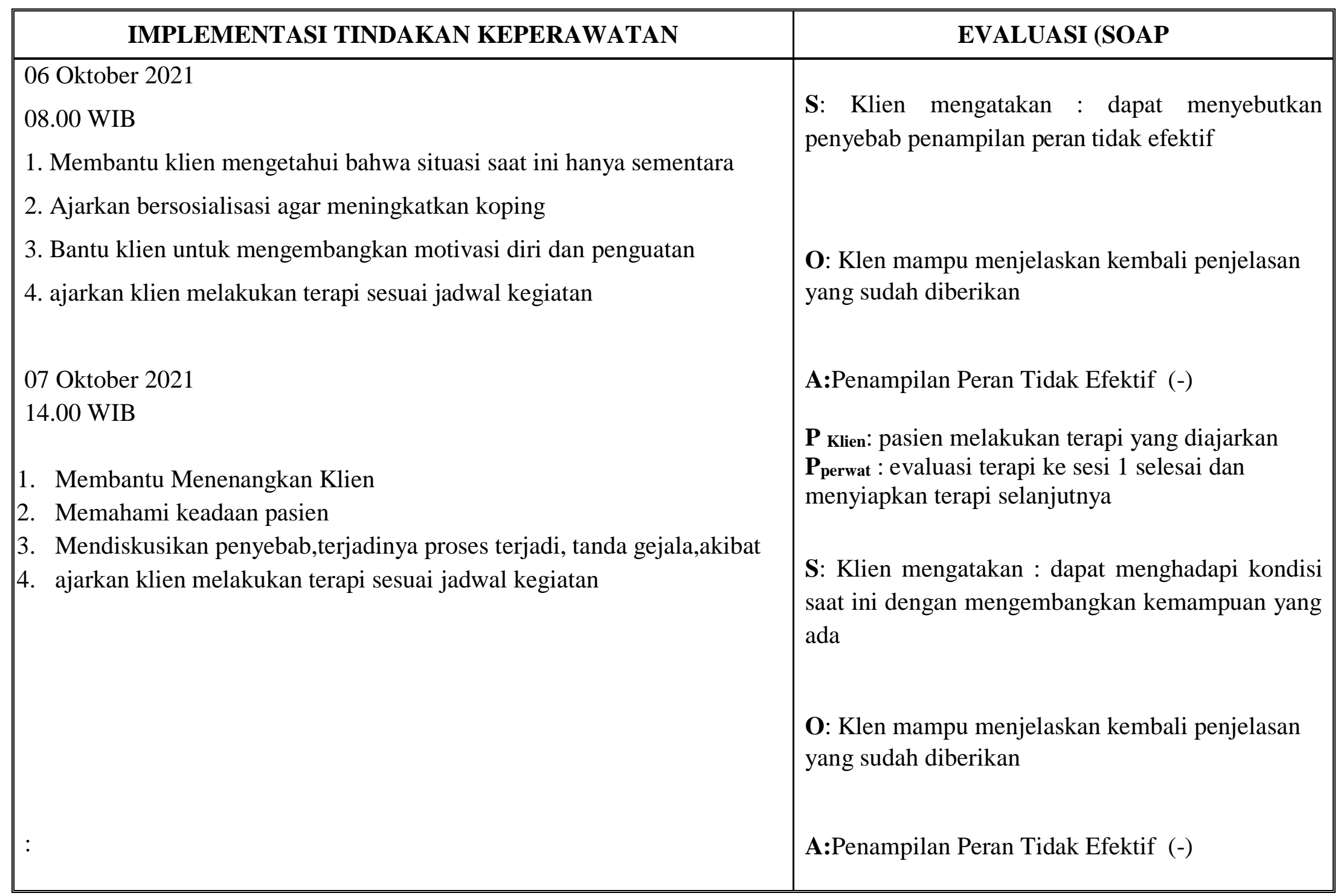




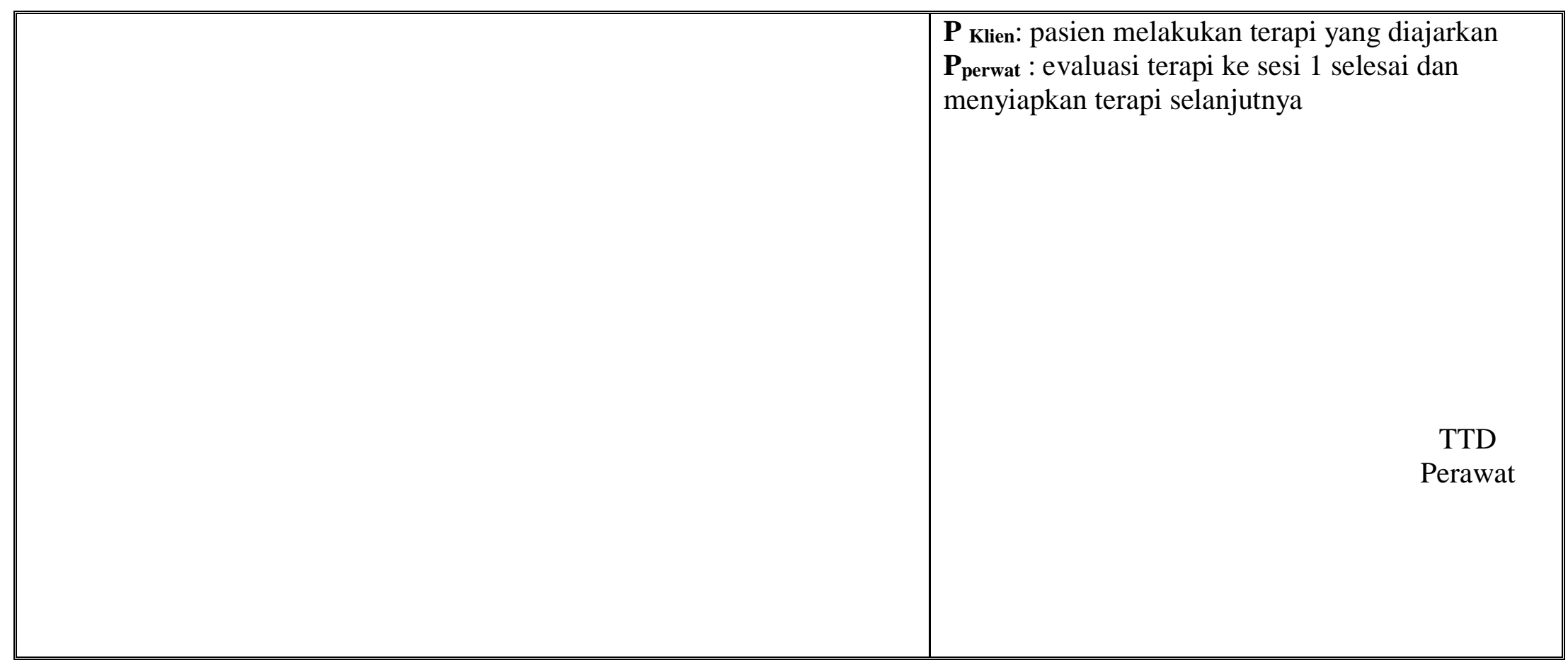




\section{BAB 4}

\section{PEMBAHASAN}

\subsection{Tahap Pengkajian}

Berdasarkan wawancara yang dilakukan oleh penulis. Penulis mendapatkan hasil yaitu seorang perempuan bernama Ny.M Saat dilakukan pengkajian dirumahnya mengtakan sudah menderita Ca Mammae selama 2 tahun terakhir dan sudah dioperasi selalu menolak dengan keadaan tubuhnya dan tidak ingin menyentuh tubuhnya yang sudah dioperasi dengan keadaannya setiap kali kambuh. Ny. M mengatakan saat bernapas, napas nya pendek, saat dilakukan pengukuran tekanan darah didapatkan hasil 90/80 $\mathrm{mmHg}$, diare dan gelisah.

Pasien memiliki 1 orang abang laki-laki dan adik perempuan yang tinggal dirumah dengan keluarganya. Saat sedang merasa lelah Ny. M bercerita dengan orangtuanya. Penampilan pasien rapi dan bersih, ramah dan mau menceritakan semua hal yang dialaminya. Saat dilakukan pemberian terapi pasien bisa mengikuti instruksi yang diberikan. Evaluasi yang saya lakukan terapi 1 berhasil dan dilanjutkan dengan pemberian terapi ke 2. Pembahasan dimulai melalui tahapan proses keperawatan yaitu pengkajian, diagnosa keperawatan, perencanaan, pelaksanaan dan evaluasi.

Pada tahap evaluasi penulis hanya dapat melaksanakan diagnosa keperawatan yang pertama saja. Pada evaluasi yang diharapkan adalah :

a. Membina hubungan saling percaya

b. Mengenali dan mengekspresikan emosinya

c. Mampu mengenal gangguan citra tubuh

d. Mampu mengatasi gangguan citra tubuh melalui teknik releksasi

e. Mampu mengatasi gangguan citra tubuh melalui kegiatan spritual

\section{BAB 5}




\section{PENUTUP}

\subsection{Kesimpulan}

Berdasarkan konsep asuhan keperawatan yang telah disusun dan dilaksanakan kepada Ny. M dimiliki dari pengkajian, rumusan masalah, perencanaan, pelaksanaan hingga evaluasi didapat hasil bahwa Ny. M dengan keluhan utama merasa malu dengan kondisi payudaranya, masih merasakan nyeri pada bagian bekas operasi. pasien menarik diri dari lingkungannya. Data objektif yaitu klien tampak lemas, bingung, sering khawatir dan cemas. Dari masalah masalah diatas maka diperoleh prioritas masalah yang diangkat adalah tentang gangguan citra tubuh. Kemudian diberikan intervensi secara konsep yaitu terapi kognitif perilaku, terapi distraksi, hipnotis lima jari dan pendidikan kesehatan. Dari hasil implementasi ada beberapa intervensi yang berhasil teratasi seperti klien mengatakan sudah lebih tenang dan rasa malu dengan keadaannya sedikit berkurang dan mampu mengenali gejala, tanda, penyebab dan akibat dari kehilangan anggotatubuh. Sedangkan klien masih bingung dalam melakukan terapi hipnotis lima jari maka intervensi dilanjutkan.

\subsection{Saran}

Diharapkan bagi perawat selalu berkoordinasi dengan tenaga kesehatan lainnya dalam memberikan asuhan keperawatan agar lebih maksimal terkhusus pada klien dengan gangguan citra tubuh pada penyakit yang mengancam nyawa.

\section{DAFTAR PUSTAKA}


1. Bulu, Kristina Tafina, 2020. Hubungan Citra Tubuh Dengan Kualitas Hidup Pasien Ca.Mammae Di Rumah Sakit Baptis Batu. Malang: Universitas Tribhuwana

https://rinjani.unitri.ac.id/bitstream/handle/071061/631/RINJANI\%20FIX\%20 KE\%202\%20-\%20Djagolado\%20Inno.pdf?sequence $=1 \&$ isAllowed $=y$

2. Guntari \& Suariyani, 2016. Nursing Interventions Classification (NIC). Singapore : Elsevier.

https://www.elsevier.com/books/nursing-interventions-classificationnic/bulechek/978-0-323-10011-3

3. Idris, Maryam Hanifah B. 2015. Kualitas Hidup Pada Penderita Kanker Dengan Status Sosial Ekonomi Rendah. Jurnal Keperawatan 2 (3). Universitas Muhammadiyah Surakarta. http://eprints.ums.ac.id/34738/

4. Stuart. Gail. W, Keliat. Budi. Anna,\& Pasaribu. Jesika.(2016). Keperawatan kesehal11tan jiwa: Indonesia : Elsever.

5. Pardede, J. A., Hutajulu, J., \& Pasaribu, P. E. (2020). Harga Diri dengan Depresi Pasien Hiv/aids. Jurnal Media Keperawatan: Politeknik Kesehatan Makassar, 11(01). https://core.ac.uk/download/pdf/328166934.pdf

6. Hamud, Waliyo \& Mustikasari, 2017. Peran Pasien san Suami Tentang pengaruh Mastektomi Terhadap Citra Tubuh. Jurnal Keperawatan 1 (2)

7. Pardede, J. A. (2020). Terapi Keluarga. https://osf.io/preprints/a $7 \mathrm{~m} 2 \mathrm{~d} /$

8. Hamdani, Laura Sri. 2017. Gambaran Citra Tubuh Pasien Paska Operasi Fraktur Ekstremitas Bawah di Rumah Sakit TK II Putri Hijau Medan. Universitas Sumatera Utara.

9. Marbun, A., Pardede, J. A., \& Perkasa, S. I. (2019). Efektivitas Terapi Hipnotis Lima Jari terhadap Kecemasan Ibu Pre Partum di Klinik Chelsea Husada Tanjung Beringin Kabupaten Serdang Bedagai. Jurnal Keperawatan Priority, 2(2), 92-99.

10. Riskesdas, 2018. Riset Kesehatan Dasar (Riskesdas). Jakarta: Kemenkes RI.

11. Herdman, T. Heather. 2016. Diangnosis Keperawatan Definisi dan Klasifikasi 2015- 2017 Edisi 10. Jakarta : EGC. 
12. Zaini, M. (2019). Asuhan keperawatan Jiwa Masalah Psikososial Di Pelayanan Klinis dan Komunitas. Deepublish : Yogyakarta.

13. Irman,Violina, dkk. 2016. Buku Ajar Ilmu Keperawatan Jiwa 1. Padang : UNP Press. 